\title{
Evaluation of the behavior of mortars produced with fibers from the straw of carnauba: effects of the content of addition and length used
}

\author{
Avaliação do comportamento de argamassas \\ produzidas com fibras da palha da carnaúba: \\ efeitos do teor de adição e comprimento utilizados
}

\author{
Antunes França Eduardo ${ }^{1}$, Marcilene Vieira de Nóbrega ${ }^{1}$, \\ Ruan Landolfo da Silva Ferreira ${ }^{2}$
}

\footnotetext{
${ }^{1}$ Federal University of the Semi-arid Region, Department of Engineering, CEP: 59515-5000, Angicos, RN, Brazil

${ }^{2}$ Federal Institute of Education, Science and Technology of Pernambuco, Civil Construction Department, CEP: 55200000, Pesqueira, PE, Brazil.

e-mail: antunesfilho1@ hotmail.com,marcilenenobrega@ufersa.edu.br, ruan.ferreira@pesqueira.ifpe.edu.br
}

\begin{abstract}
The rendering mortars must be able to absorb small deformations, in order to guarantee the stability of the masonry (performance and durability). When this premise is not met, there is a greater propensity for the appearance of cracks, one of the main and worrying pathological manifestations in mortar coverings. One of the alternatives to combat this pathological manifestation is the addition of natural/artificial fibers in order to improve the mechanical properties (mainly the traction strength) and, consequently, the deformation capacity of the mortar. In this perspective, this work analyzed the behavior in the fresh and hardened state of mortars with the addition of fibers obtained from the straw of the carnauba (Copernicia prunifera), an abundant tree in the region of the Açu valley/RN (Brazil). For this purpose, mortars were produced in a 1:3 mass ratio (binder:aggregate) with the addition of $3 \%$ and $5 \%$ fiber from the carnauba straw (CSF) in relation to the cement mass and with the water/cement ratio (w/c) fixed at 0.72 for all mixtures. The effects of using fibers with different lengths $(20,40$ and $60 \mathrm{~mm})$ were also investigated. The properties of mortars were evaluated in a fresh (consistency) and hardened (compression and flexural strengths) state. The results indicated that the addition of CSF results in mortar with less consistency and mechanical strength. However, in general, the best performance was obtained for additions of up to $3 \%$ and for longer fiber lengths $(20 \mathrm{~mm})$.
\end{abstract}

Keywords: Vegetable fibers. Carnauba. Mortar with fibers.

\begin{abstract}
RESUMO
As argamassas de revestimento devem ser capazes de absorver pequenas deformações, de modo a garantir a estabilidade das alvenarias (desempenho e durabilidade). Quando essa premissa não é atendida, há uma maior propensão para o surgimento de fissuras, uma das principais e preocupantes manifestações patológicas em revestimentos argamassados. Uma das alternativas ao combate dessa manifestação patológica é a adição de fibras naturais/artificiais com o intuito de melhorar as propriedades mecânicas (principalmente a resistência à tração) e, consequentemente, a capacidade de deformação das argamassas. Nessa perspectiva, este trabalho analisou o comportamento no estado fresco e endurecido de argamassa com adição de fibras obtidas a partir da palha da carnaúba (Copernicia prunifera), árvore abundante na região do vale do Açu/RN (Brasil). Para tanto, foram produzidas argamassas em proporção em massa de 1:3 (cimento:agregado) com adição de 3\% e $5 \%$ de fibra da palha da carnaúba (FPC) em relação à massa do cimento e com relação água/cimento (a/c) fixa em 0,72 para todas as misturas. Os efeitos da utilização de fibras com diferentes comprimentos $(20,40 \mathrm{e}$ $60 \mathrm{~mm}$ ) também foi investigado. As propriedades das argamassas foram avaliadas no estado fresco (consistência) e endurecido (resistência à compressão e à tração na flexão). Os resultados indicaram que a adição de FPC resulta em argamassa com menores consistência e resistências mecânicas. Entretanto, em geral, o melhor desempenho foi obtido para adições de até $3 \%$ e maiores comprimentos de fibra $(20 \mathrm{~mm})$.
\end{abstract}


Palavras-chave: Fibras vegetais. Carnaúba. Argamassa com fibras.

\section{INTRODUCTION}

Mortars are construction materials that plays an important role in the thermal and acoustic behaviour of buildings. In general, rendering mortars must have moderate strength, watertightness, good adhesion to the substrate and high deformability [1]. In particular deformability, mortars need to absorb small deformations to prevent cracking and, consequently, to prevent the performance of building sealing systems from being impaired. Due to the difficulty in avoiding it, cracking is considered one of the most common anomalies in lining mortars (non-structural), which can compromise the water impermeability, performance and durability of the masonry [2].

One of the most efficient alternatives in an attempt to improve the behavior of non-structural mortars as to the appearance of cracks is the addition of fibers. From an environmental point of view, the use of fibers in cementitious composites does not cause any harmful effect to the environment. [3]. Technically, the fibers absorb the internal stresses generated in the structure [4], thus preventing the mortar from presenting plastic shrinkage and cracks in the hardened state [5]. As a result, the tensile strength, hardness and durability of the materials are improved [6].

Currently, there is a need to seek alternatives that have a low environmental impact and that contribute to improving the performance of Portland cement-based composites. Within this context, the possibility of using natural fibers to replace synthetic fibers is inserted, such as: polypropylene [7], steel [8], glass [9] and carbon [10], among others, for composites production. The reasons seem clear, since compared to synthetic fibers, natural fibers have a relatively low cost, low density, contribute to sustainable development and have favorable mechanical properties for various applications in civil construction [3,6,11-16]. Therefore, the use of natural fibers as a raw material for cement-based materials fosters environmental, energy and resource conservation [17].

Many of these natural fibers have the potential to be used to reinforce cementitious materials, such as wood fibers [18], coconut [19-22], sisal [23, 24], jute [6], bamboo [25], etc. In particular, fibers of plant origin (namely, cellulosic fibers), in recent years, there has been an increase in interest in their use as reinforcements in composites. This observed interest is due to the fact that they are natural materials widely available at a relatively low cost and that have interesting characteristics such as bio-renewability, recycling capacity, biodegradability and others. [3, 11, 17].

However, much of the current studies are focused on investigating the use of these fibers (coconut and sisal, mainly) in cementitious composites are exhaustive. For this reason, little attention is paid to other types of raw material, such as fibers obtained from tree straw. In these scenarios, it is noted that studies on the addition of fibers from the carnauba straw (CSF) in cement-based composites are limited in national and international literature, neglecting their potential as a reinforcement material in coating mortars.

The CSF is obtained from carnauba (Copernicia prunifera), a palm native to the semi-arid region of northeastern Brazil, whose main product is carnauba wax. Wax has several applications in the pharmaceutical industry, food industry, cosmetics, electronic components, greases and lubricants and as mold release [2629]. After the extraction of the wax, approximately 352 thousand tons of lignocellulosic waste is generated per year [30,31], which constitutes an important and favorable scenario for the use of this biomass.

Of the few studies found in the national and international bibliography, two research are highlighted; MARQUES [32] investigated the use of carnauba straw powder as a reinforcement for polymeric chitosan composites. The results showed that the incorporation of the carnauba leaf powder without treatment causes a decrease in the mechanical properties of the composites. In another study, MELO et al. [26] evaluated the effects of different treatments of carnauba fibers on the mechanical behavior of biodegradable composites based on polyhydroxybutyrate (PHB). Among all the evaluated treatments, the best matrix-fiber adhesion was verified in composites with fibers treated in alkaline medium $(5 \% \mathrm{NaOH})$ and with peroxide, that obtained best mechanical too.

It should be noted that none of these studies investigates the use of CSF in mortars, which suggests that the present study is pioneering, promising and with the potential to encourage the emergence of new research. Based on these factors and considering that the content and length of the fibers influence the performance of composites [33], this study evaluated the effects of different percentages (3\% and 5\%) and lengths $(20 \mathrm{~mm}, 40 \mathrm{~mm}$ and $60 \mathrm{~mm}$ ) of CSF in the physical and mechanical properties of cement-based mortars. It aiming to improve the behavior of mortars with regard to cracking and contribute to obtaining sustainable built environments, favoring the circular economy due to the creation of jobs related to new uses of native 
plants in civil construction.

\section{MATERIALS AND METHODS}

\subsection{Materials}

In this study, Portland cement with high initial resistance and resistant to sulfates (CPV-ARI-RS) was used, with specific density and compressive strength equal to $3.10 \mathrm{~g} / \mathrm{cm}^{3}$ and $54.1 \mathrm{MPa}$ at 28 days, respectively. The use of this cement is justified because it is the most commercialized type in the region. Natural sand obtained from a river bed with a specific density of $2.61 \mathrm{~g} / \mathrm{cm}^{3}$ was used as fine aggregate for the manufacture of mortars. Before being used, the sand was sieved in the laboratory to remove particles larger than $2.36 \mathrm{~mm}$ and subsequently dried in an oven $(105 \pm 5){ }^{\circ} \mathrm{C}$ for 48 hours.

Carnauba straw fibers (CSF) were obtained from carnauba trees located in the city of Carnaubais/RN. For the preparation of the CSF the following procedures were adopted: (i) initially, the straws were collected from the carnauba trees and dried naturally for 15 days; (ii) then, the straws were cut manually in order to obtain filaments (that is, the CSF) approximately $15 \mathrm{~mm}$ thick and with lengths of 20, 40 and $60 \mathrm{~mm}$, as can be seen in Figure 1; (iii) Finally, the CSF were washed with distilled water to remove any residues present and then dried in an oven $(105 \pm 5){ }^{\circ} \mathrm{C}$ for 48 hours.

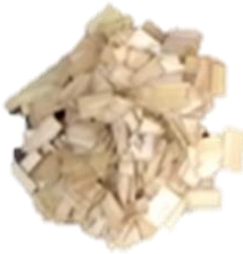

$20 \mathrm{~mm}$

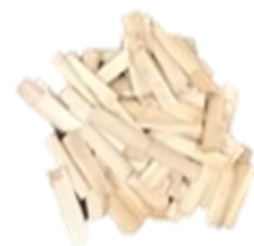

$40 \mathrm{~mm}$

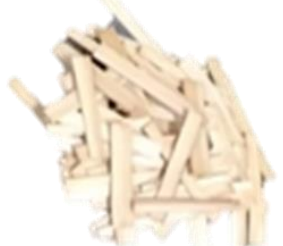

$60 \mathrm{~mm}$

Figure 1: Fibers cut to pre-established sizes.

Fig. 2 shows the CSF morphology obtained by scanning electron microscopy (SEM). It can be seen that the CSF surface is porous, with cells in an alveolar shape. At first, these characteristics may favor the adhesion between the cement paste and the CSF. However, a porous surface results in greater water absorption [17].

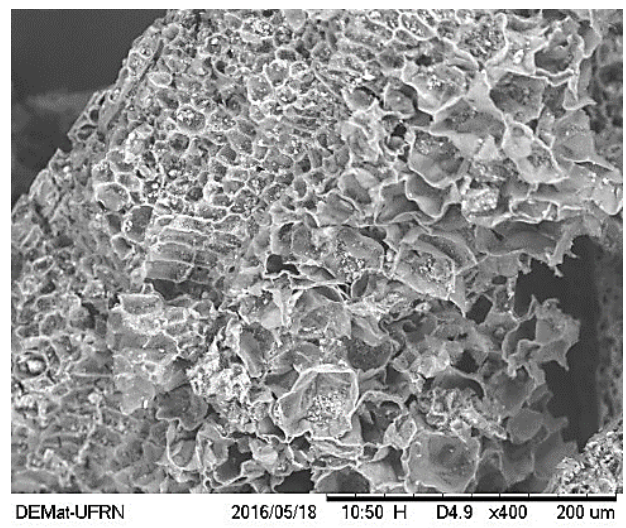

Figure 2: Micrograph of the CSF surface.

\subsection{Mortar Production}

For the production of mortars, the following criteria were established:

- A mixing ratio by weight of 1:3 (cement:sand) was used. The choice of this feature was due to its wide use in civil construction works in the region; 
- Based on a preliminary study, it was defined that the ideal water/cement ratio (w/c) would be fixed at 0.72 for all mortars studied, in order to obtain workable mixtures. This assessment was carried out through the consistency test, according to procedures established by NBR 13276 [34];

- The fibers were added at percentages of 3 and $5 \%$ in relation to the cement weight. The choice of these contents was based on preliminary studies and also on previous studies that showed that high natural fiber contents contribute to reduce the workability of mortars [3, 33];

- Three lengths of CSF were used: 20, 40 and $60 \mathrm{~mm}$.

Mortars were mixed in a standard mechanical mixer according to the procedure described by the Brazilian standard NBR 16541 [35]. With these conditions established, a total of seven mixtures were produced: one reference (REF) and six with variation of the percentage of addition and the length of the CSF. The amount of each material used in these mixtures is shown in Table 1.

Table 1: Mixture proportions required to produce of mortars.

\begin{tabular}{c|c|c|c|c|c|c|c}
\hline \multirow{2}{*}{$\begin{array}{c}\text { MIXTURES } \\
\text { DESIGN }\end{array}$} & \% CSF & \multirow{2}{*}{ CEMENT (G) } & \multirow{2}{*}{ SAND (G) } & \multicolumn{3}{|c|}{ CSF LENGTHS (G) } & \multirow{2}{*}{ W/C } \\
\cline { 5 - 7 } & & & & $\mathbf{2 0} \mathbf{~ M M}$ & $\mathbf{4 0} \mathbf{~ M M}$ & $\mathbf{6 0 ~ M M ~}$ & \\
\hline REF & 0.0 & 750.0 & 2250.0 & 0.0 & 0.0 & 0.0 & 0.72 \\
\hline 3CSF20 & 3.0 & 750.0 & 2250.0 & 22.5 & 0.0 & 0.0 & 0.72 \\
\hline 3CSF40 & 3.0 & 750.0 & 2250.0 & 0.0 & 22.5 & 0.0 & 0.72 \\
\hline 3CSF60 & 3.0 & 750.0 & 2250.0 & 0.0 & 0.0 & 22.5 & 0.72 \\
\hline 5CSF20 & 5.0 & 750.0 & 2250.0 & 37.5 & 0.0 & 0.0 & 0.72 \\
\hline 5CSF40 & 5.0 & 750.0 & 2250.0 & 0.0 & 37.5 & 0.0 & 0.72 \\
\hline 5CSF60 & 5.0 & 750.0 & 2250.0 & 0.0 & 0.0 & 37.5 & 0.72 \\
\hline
\end{tabular}

\subsection{Tests performed on mortars}

During the first 24-hour, the surface of the specimens was protected with a glass plate to prevent evaporation of the mixing water. After the demolding process, they were immersed in solution of water-lime for 28 days, i.e., until the testing stage. Details on the size and numbers of the samples with the applicable normative procedures are listed in Table 2.

Table 2: Mortar characterization test.

\begin{tabular}{l|l|c|c}
\hline \multicolumn{1}{c|}{ PROPERTIES } & STANDARD & SPECIMENS & SIZE OF SPECIMENS \\
\hline Fresh state & NBR 13276 [34] & 3 & \\
\hline Consistency by flow table & NBR 13279 [36] & 3 & Prismatic $(40 \times 40 \times 160 \mathrm{~mm})$ \\
\hline Hardened state & NBR 13279 [36] & 6 & Prismatic $(40 \times 40 \times 160 \mathrm{~mm})$ \\
\hline Flexural strength &
\end{tabular}

\section{RESULTS AND DISCUSSION}

\subsection{Consistency of fresh mortars}

Figure 3 shows the results of consistency test of the mortars. Regardless of the content of addition and length of fiber used, the incorporation of CSF resulted in mortars with less consistency (less fluidity), which may indicate less workability. The reason for this result can be explained due to the porous surface of the CSF (Fig. 2), which results in a greater absorption of water from the mixture, thus reducing the flow capacity of the mortars. These results are consistent with previous studies [7, 16, 37]. These decreases in workability reported by these authors are mainly due to the hydrophilic characteristic of natural vegetable fibers [17] which absorbs part of the water of hydration, resulting in a reduction in the workability of cement mixtures. 
On the other hand, this effect can be mitigated by performing alkaline treatments based on $\mathrm{NaOH}$, as seen in previous studies $[17,38]$.

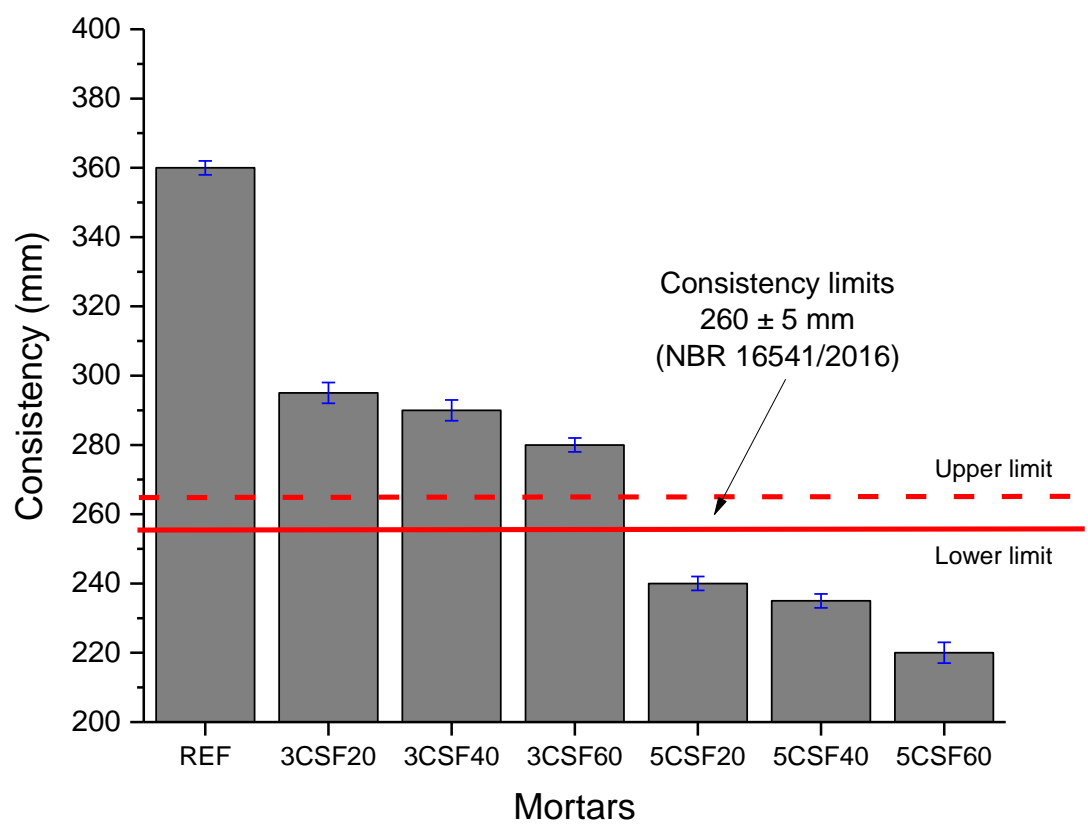

Figure 3: Consistency of fresh mortars reinforced with fiber from the carnauba straw (CSF).

For higher levels of addition of CSF, the consistency has been reduced to values below the minimum limit established by standard so that the mortars have adequate consistency when applied to wall and ceiling coverings. This can be explained by the phenomenon that CSF tend to mix with the cement grains and involve the aggregate particles, making it difficult for the mortar to deform and flow. However, if we consider the consistency table required by the European standard UNE-EN 1015-3:1999 [39] (175 $\pm 10 \mathrm{~mm})$, the production of mortars with 5\% CSF is feasible.

\subsection{Compressive strength}

Figure 4 shows the results obtained with the compressive strength test of mortars reinforced with different CSF contents and lengths. Unlike concretes, mortars do not need high strengths to be applied to masonry. However, it is necessary that these materials have good resistance in order to withstand small stresses arising from thermal movements and remain attached to the substrate. 


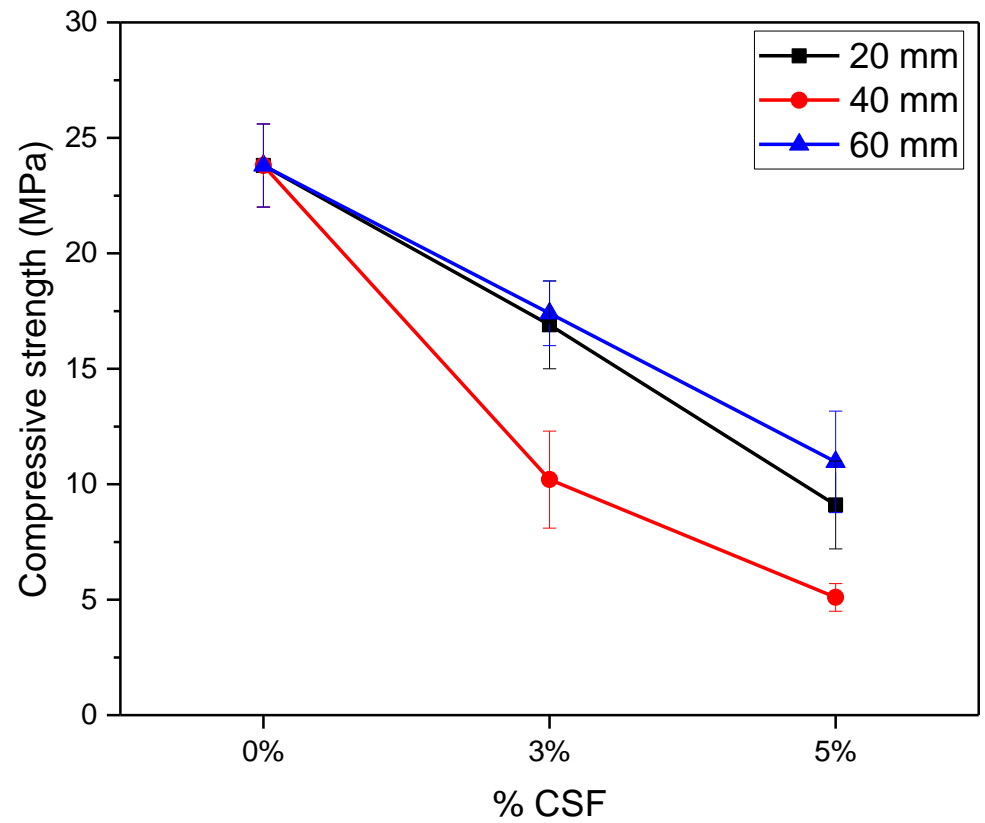

Figure 4: Compressive strength of mortars reinforced with fiber from the carnauba straw (CSF).

Regarding the addition content, it is noted that as the CSF content increased, the compressive strength decreased. These observations are consistent with a previous study [40]. As for the overlapping effects, it should be noted, above all, that the higher CSF content increases the amount of voids in the mixture and this makes the mortars less compact and, therefore, less resistant. This behavior could probably be due to the superposition of some phenomena: (i) poor distribution of fibers within the matrix [23, 40, 41], which gives less load bearing capacity; (ii) durability of the fiber within the matrix due to the attack of calcium hydroxide [17, 23, 41], resulting in loss of mechanical strength; (iii) the hydrophilic nature of the fibers of plant origin and, consequently, the greater absorption of water [17] explain the obtaining of less compact mixtures, as previously discussed. This characteristic also causes the fibers to undergo dimensional variation due to the water loss process during hydration of the cementitious matrix [42]. As a result, there is a detachment of the fiber in the matrix and, therefore, it is expected that mortars with higher CSF content show a reduction in their mechanical behavior.

It was also observed that the use of long CSF $(60 \mathrm{~mm})$ contributed to obtain better results, which can be attributed to the increase in the ductility of the mortar. As the length increases, the fibers act as retardants in the crack openings. Thus, when the compression is broken, the stresses are absorbed by the fibers and the material has a pronounced deformation capacity. Similar observations were made by SILVA, et al. [43] when studying the effects of adding coconut fiber on the compression strength of mortars.

\subsection{Flexural strength}

The incorporation of CSF regardless of the content and length incorporated resulted in mortars with less resistance to bending, as shown in Figure 5. Bearing in mind that this mechanical property is influenced by the porosity of the matrix [41], it can be inferred that a higher fiber content contributes to obtain less compact mixtures due to the fiber dispersion deficiency in the cementitious matrix. As a result, mortars with lower flexural strength are obtained. 


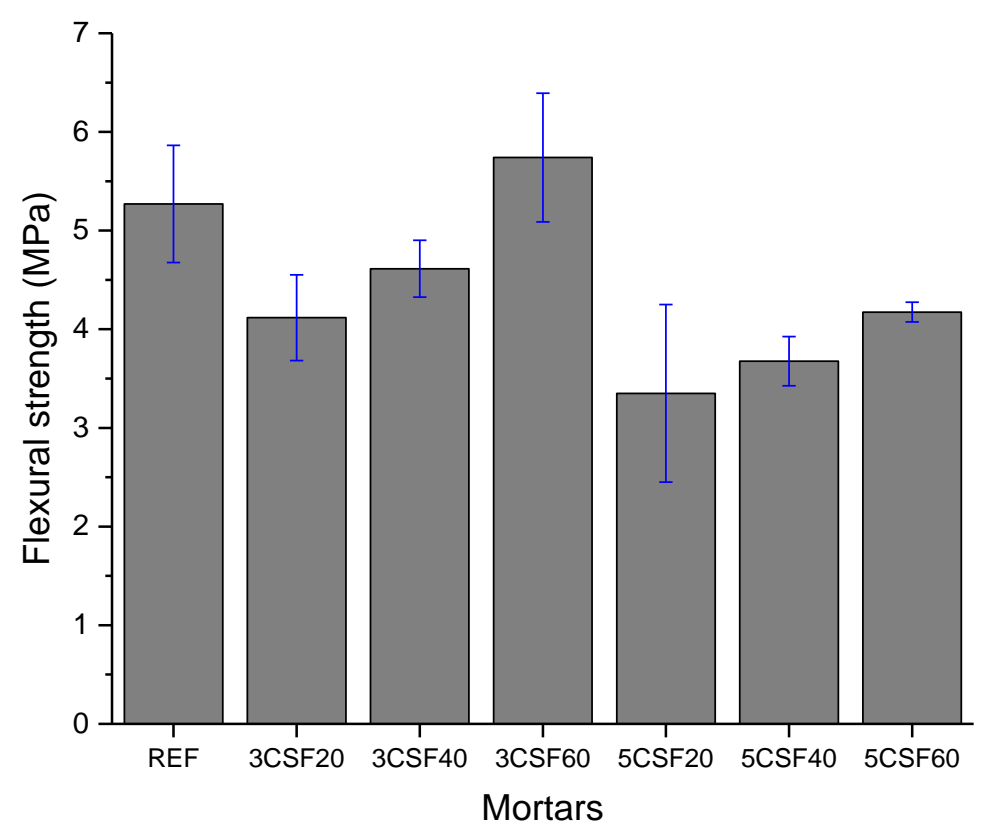

Figure 5: Flexural strength of mortars reinforced with fiber from the carnauba straw (CSF).

In a recent study, TEIXEIRA et al. [41] observed that the inclusion of curauá fibers, while increasing the toughness and reinforcement of composites, the transfer of tension between the fibers and the matrix is deficient. This may explain the decrease in the flexural strength of mortars with the incorporation of CSF. However, it was observed that with increasing fiber length, the flexural behavior is improved, regardless of the incorporated content ( $3 \%$ or $5 \%$ ). This characteristic is appreciable because higher tensile strengths suggest mortars with greater capacity to resist retraction stresses [44]. Thus, susceptibility to cracking will be less.

The highest values of flexural strength were obtained for the combination of greater fiber length with less fiber, as shown in Figure 5. The addition of 3\% CSF in $20 \mathrm{~mm}$ and $40 \mathrm{~mm}$ lengths (3CSF20 and $3 \mathrm{CSF} 40$, respectively) showed a $20 \%$ reduction and $12 \%$, respectively, in the flexural strength compared to the reference mortar (REF). On the other hand, the mortar produced with CSF of $60 \mathrm{~mm}$ obtained flexural strength superior to that of the reference mortar, whose increase was $10 \%$. As reported by PELLEGRIN et al. [44] longer fibers provide better mechanical performance, especially in flexural strength. These authors comment that this improved performance is due to the acting of the fibers as a bridge between the openings of a crack during its propagation. This is important because the addition of CSF improves the tensile strength in flexion and, consequently, can contribute to delay the appearance of cracks in mortars.

As previously discussed, in general, fibers increase the ductility of mortar [45], which contributes to the increase in flexural strength and provides a delay in crack opening, as well as a reduction in its width [46]. Although a reduction in the properties of compressive and flexural strengths has been observed, it must be recognized that the incorporation of CSF improves the deformation capacity of mortars, which is appreciable for the good performance and durability of the rendering mortars.

\section{CONCLUSIONS}

The use of carnauba straw as fiber for reinforcing cement-based mortars was investigated in this research. For that, mortars were produced with different percentages of addition (3\% and 5\%) and length (20, 40 and $60 \mathrm{~mm}$ ) of carnauba straw fiber (CSF). The properties of mortars were changed by the incorporation of CSF, regardless of the content or length used. Consistency of fresh mortar and compressive strength have been reduced as CSF content and length have increased. The inefficient distribution of fibers in the matrix was decisive for obtaining less resistant mixtures. The flexural strength in flexion has been improved with the incorporation of CSF, especially in the $3 \%$ incorporation with length of $60 \mathrm{~mm}$ has been combined. Thus, although there is a need for more specific studies for improving the stability of the fiber in the matrix and evaluating other properties of mortars, it is admitted that it is possible to use CSF to reinforce cement-based mortars. Notwithstanding, these results are expected to contribute to foment sustainable development and promote the circular economy in civil construction. 


\section{BIBLIOGRAPHY}

[1] SANTOS, A.R., ROSÁRIO VEIGA, M., MATIAS, L., et al., Durability and compatibility of lime-based mortars: The effect of aggregates, Infrastructures. https://doi.org/10.3390/infrastructures3030034. v. 3, pp. 112, 2018.

[2] VEIGA, M.R. Influence of application conditions on the cracking susceptibility of renderings, Concr. Sci. Eng. v. 2, pp. 131-140, 2000.

[3] ARDANUY, M., CLARAMUNT, J., TOLEDO FILHO, R.D. Cellulosic fiber reinforced cement-based composites: A review of recent research, https://doi.org/10.1016/j.conbuildmat.2015.01.035. Constr. Build. Mater. v. 79, pp. 115-128, 2015.

[4] SANTOS, A.G., RINCÓN, J.M., ROMERO, M., et al., Characterization of a polypropylene fibered cement composite using ESEM, FESEM and mechanical testing, Constr. Build. Mater. https://doi.org/10.1016/j.conbuildmat.2004.07.023. v. 19, pp.396-403, 2005.

[5] SONG, P.S., HWANG, S., SHEU, B.C. Strength properties of nylon- and polypropylene-fiber-reinforced concretes, Cem. Concr. Res. https://doi.org/10.1016/j.cemconres.2004.06.033. v. 35, 2005, pp. 1546-1550.

[6] KESIKIDOU, F., STEFANIDOU, M. Natural fiber-reinforced mortars, J. Build. Eng. https://doi.org/10.1016/j.jobe.2019.100786. v. 25, p. 100786, 2019.

[7] LI, L.G., ZHAO, Z.W., ZHU, J., et al., Combined effects of water film thickness and polypropylene fibre length on fresh properties of mortar, Constr. Build. Mater.

https://doi.org/10.1016/j.conbuildmat.2018.03.259. v. 174, pp. 586-593, 2018.

[8] HAN, J., ZHAO, M., CHEN, J., et al., Effects of steel fiber length and coarse aggregate maximum size on mechanical properties of steel fiber reinforced concrete, Constr. Build. Mater.

https://doi.org/10.1016/j.conbuildmat.2019.03.086. v. 209, pp. 577-591, 2019.

[9] TREJBAL, J., Mechanical properties of lime-based mortars reinforced with plasma treated glass fibers, Constr. Build. Mater. https://doi.org/10.1016/j.conbuildmat.2018.09.175. v. 190, pp. 929-938, 2018.

[10] NGUYEN, H., CARVELLI, V., FUJII, T., et al., Cement mortar reinforced with reclaimed carbon fibres, CFRP waste or prepreg carbon waste, Constr. Build. Mater.

https://doi.org/10.1016/j.conbuildmat.2016.09.044. v. 126, pp. 321-331. 2016.

[11] BLEDZKI, A.K., GASSAN, J. Composites reinforced with cellulose based fibres, Prog. Polym. Sci. https://doi.org/10.1016/S0079-6700(98)00018-5. 1999.

[12] WAMBUA, P., IVENS, J., VERPOEST, I. Natural fibres: Can they replace glass in fibre reinforced plastics?, Compos. Sci. Technol. https://doi.org/10.1016/S0266-3538(03)00096-4. 2003.

[13] KU, H., WANG, N. Pattarachaiyakoop, M. Trada, A review on the tensile properties of natural fiber reinforced polymer composites, Compos. Part B Eng. https://doi.org/10.1016/j.compositesb.2011.01.010. 2011.

[14] SOOD, M., DWIVEDI, G. Effect of fiber treatment on flexural properties of natural fiber reinforced composites: A review, Egypt. J. Pet. https://doi.org/10.1016/j.ejpe.2017.11.005. 2018.

[15] FONSECA, C.S., SILVA, M.F., MENDES, R.F., et al., Jute fibers and micro/nanofibrils as reinforcement in extruded fiber-cement composites, Constr. Build. Mater. https://doi.org/10.1016/j.conbuildmat.2019.03.236. v. 211, pp. 517-527, 2019.

[16] B. ÇOMAK, A. BIDECI, Ö. SALLI BIDECI, Effects of hemp fibers on characteristics of cement based mortar, Constr. Build. Mater. https://doi.org/10.1016/j.conbuildmat.2018.03.029. v. 169, pp. 794-799, 2018.

[17] ONUAGULUCHI, O., BANTHIA, N. Plant-based natural fibre reinforced cement composites: A review, Cem. Concr. Compos. https://doi.org/10.1016/j.cemconcomp.2016.02.014. v. 68, pp. 96-108, 2016.

[18] PIZZOL, V.D., MENDES, L.M., FREZZATTI, L., et al., Effect of accelerated carbonation on the microstructure and physical properties of hybrid fiber-cement composites, Miner. Eng.

https://doi.org/10.1016/j.mineng.2013.11.007. v. 59, pp. 101-106, 2014.

[19] JOHN, V.M., CINCOTTO, M.A., SJÖSTRÖM, C., et al., Durability of slag mortar reinforced with coconut fibre, in: Cem. Concr. Compos., https://doi.org/10.1016/j.cemconcomp.2004.09.007. 2005.

[20] HWANG, C.L., TRAN, V.A., HONG, J.W., et al., Effects of short coconut fiber on the mechanical properties, plastic cracking behavior, and impact resistance of cementitious composites, Constr. Build. Mater. https://doi.org/10.1016/j.conbuildmat.2016.09.118. 2016. 
[21] ALI, M., LIU, A., SOU, H., et al., Mechanical and dynamic properties of coconut fibre reinforced concrete, Constr. Build. Mater. https://doi.org/10.1016/j.conbuildmat.2011.12.068. 2012.

[22] SATHIPARAN, N., RUPASINGHE, M.N., PAVITHRA, B.H.M. Performance of coconut coir reinforced hydraulic cement mortar for surface plastering application, Constr. Build. Mater. https://doi.org/10.1016/j.conbuildmat.2017.03.058. 2017.

[23] SAVASTANO, H.P., WARDEN, R.S.. Coutts, Brazilian waste fibres as reinforcement for cement-based composites, Cem. Concr. Compos. https://doi.org/10.1016/S0958-9465(00)00034-2. v. 22, pp. 379-384, 2000 .

[24] SANTOS, S.F., SCHMIDT, R., ALMEIDA, A.E.F.S., et al., Supercritical carbonation treatment on extruded fibre-cement reinforced with vegetable fibres, Cem. Concr. Compos.

https://doi.org/10.1016/j.cemconcomp.2014.11.007. 2015.

[25] COUTTS, R.S.P., NI, Y. Autoclaved bamboo pulp fibre reinforced cement, Cem. Concr. Compos. https://doi.org/10.1016/0958-9465(94)00002-G. 1995.

[26] MELO, J.D.D., CARVALHO, L.F.M., MEDEIROS, A.M., et al., biodegradable composite material based on polyhydroxybutyrate (PHB) and carnauba fibers, Compos. Part B Eng. https://doi.org/10.1016/j.compositesb.2012.04.046. v. 43, pp. 2827-2835, 2012.

[27] SOUSA, R.F., SILVA, R.A.R., ROCHA, T.G.F., et al., Ethnoecology and ethnobotany of the palm carnauba wax in Brazilian semi-arid, Cerne. https://doi.org/10.1590/01047760201521041764. 2015.

[28] SILVA, F.L., OLIVEIRA CAMPOS, A., SANTOS, D.A., et al., Pretreatments of Carnauba (Copernicia prunifera) straw residue for production of cellulolytic enzymes by Trichorderma reesei CCT-2768 by solid state fermentation, Renew. Energy. https://doi.org/10.1016/j.renene.2017.09.064. 2018.

[29] ANDRADE, L.B.S., JULIÃO, M.S.S., CRUZ, R.C.V., et al., Antioxidant and antifungal activity of carnauba wax powder extracts, Ind. Crops Prod. https://doi.org/10.1016/j.indcrop.2018.09.004. 2018.

[30] CARVALHO, F.P.A., GOMES, J.M.A. Eco-eficiência na produção de cera de Carnaúba no município de Campo Maior, Piauí, 2004, Rev. Econ. e Sociol. Rural. https://doi.org/10.1590/s010320032008000200006. v. 46, pp. 421-453, 2008.

[31] GOMES, J.A.F., LEITE, E.R., CAVALCANTE, A.C.R., et al., Resíduo agroindustrial da carnaúba como fonte de volumoso para a terminação de ovinos, Pesqui. Agropecu. Bras.. https://doi.org/10.1590/S0100-204X2009000100009. 2009.

[32] MARQUES, J.S. Uso do pó da palha de carnaúba em compósitos de quitosana, Universidade Federal do Rio Grande do Norte, 2012.

[33] BRITO, J., VEIGA, M., PEDERNEIRAS, C. Effects of the Incorporation of Waste Fibres on the Cracking Resistance of Mortars: A Review, https://doi.org/10.30634/2414-2077.2018.04.5. Int. J. Green Technol. v. 4, pp. 38-46. 2018.

[34] ABNT. NBR 13276, Mortars applied on walls and ceilings - Determination of the consistence index, ABNT - Associação Brasileira de Normas Técnicas, Rio de Janeiro, pp. 2-4, 2016.

[35] ABNT. NBR 16541, Argamassa para assentamento e revestimento de paredes e tetos - Preparo da mistura para a realização de ensaios, ABNT - Associação Brasileira de Normas Técnicas, Rio de Janeiro, https://doi.org/01.080.10; 13.220.99. pp. 1-8, 2016.

[36] ABNT. NBR 13279, Mortars applied on walls and ceilings - Determination of the flexural and the compressive strength in the hardened stage, ABNT - Associação Brasileira de Normas Técnicas, Rio de Janeiro, pp. 1-13, 2005.

[37] MANSUR, M.A., AZIZ, M.A. A study of jute fibre reinforced cement composites, Int. J. Cem. Compos. Light. Concr. https://doi.org/10.1016/0262-5075(82)90011-2. v. 4, pp. 75-82, 1982.

[38] AZEVEDO, A.R., MARVILA, M.T., ZANELATO, E.B., et al., Development of mortar for laying and coating with pineapple fibers, Rev. Bras. Eng. Agrícola e Ambient. https://doi.org/10.1590/18071929/agriambi.v24n3p187-193. v. 24, pp. 187-193, 2020.

[39] UNE-EN 1015-3, Methods of test for mortar for masonry - Part 3: Determination of consistence of fresh mortar (by flow table), 1999.

[40] BENTCHIKOU, M., GUIDOUM, A., SCRIVENER, K., et al., Effect of recycled cellulose fibres on the properties of lightweight cement composite matrix, Constr. Build. Mater. 
https://doi.org/10.1016/j.conbuildmat.2012.02.097., v. 34, pp. 451-456, 2012,.

[41] TEIXEIRA, R.S., SANTOS, S.F., CHRISTOFORO, A.L., et al., Impact of content and length of curauá fibers on mechanical behavior of extruded cementitious composites: Analysis of variance, Cem. Concr.

Compos. https://doi.org/10.1016/j.cemconcomp.2019.04.022., v. 102, pp. 134-144, 2019.

[42] TEIXEIRA, R.S., TONOLI, G.H.D., SANTOS, S.F., et al.,, Different ageing conditions on cementitious roofing tiles reinforced with alternative vegetable and synthetic fibres, Mater. Struct.

https://doi.org/10.1617/s11527-013-0070-0. v. 47, pp. 433-446, 2014.

[43] SILVA, E.J., SILVA, P.D., MARQUES, M.L., et al., Compressive strength of cement mortar prepared with the addition of coconut fiber, Rev. Bras. Eng. Agrícola e Ambient. https://doi.org/10.1590/18071929/agriambi.v18n12p1268-1273. v. 18, pp. 1268-1273, 2014.

[44] PELLEGRIN, M.Z., ACORDI, J., MONTEDO, O.R.K. Influence of the Length and the Content of Cellulose Fibers Obtained from Sugarcane Bagasse on the Mechanical Properties of Fiber-Reinforced Mortar Composites, J. Nat. Fibers. https://doi.org/10.1080/15440478.2019.1612311. pp. 1-11, 2019.

[45] ORASUTTHIKUL, S., UNNO, D., YOKOTA, H. Effectiveness of recycled nylon fiber from waste fishing net with respect to fiber reinforced mortar, Constr. Build. Mater. https://doi.org/10.1016/j.conbuildmat.2017.04.134. v. 146. pp. 594-602, 2017.

[46] FERRÁNDIZ-MAS, V., GARCÍA-ALCOCEL, E. Durability of expanded polystyrene mortars, Constr. Build. Mater. https://doi.org/10.1016/j.conbuildmat.2013.04.029. v. 46, pp. 175-182, 2013.

\section{ORCID}

Antunes França Eduardo Marcilene Vieira de Nóbrega

Ruan Landolfo da Silva Ferreira https://orcid.org/0000-0002-7069-7275

https://orcid.org/0000-0003-2509-3672

https://orcid.org/0000-0001-6744-5395 